DOI https://doi.org/10.18551/rjoas.2017-10.43

\title{
MATURATION OBSERVATION OF GONAD IN MUDSKIPPER PSEUDAPOCRYPTES ELONGATUS FROM KALI LAMONG RIVER (GRESIK, INDONESIA)
}

\author{
Fariedah Fani*, Widodo Sri Maheno, Yuwanita Rani \\ Aquaculture Study Program, Department of Fisheries Resources Utilization, \\ Faculty of Fisheries and Marine Science, University of Brawijaya, Indonesia \\ *E-mail: fanifariedah@ub.ac.id
}

\begin{abstract}
Pseudapocryptes elongatus is commonly found in river estuaries near mangroves. This fish can be caught These fish could be arrested as the water is undergoing high tide and is used as fish consumption by the inhabitants of around the north coast of java island, indonesia. The study was conducted to obtain information about the maturity of gonad and fecundity of Pseudapocryptes elongatus in Kalilamong River from July to September 2017. The fish were then dissected to do observation of the gonads. Weight, length and gonad Pseudapocryptes elongatus were weighed and measured, and then visual observations were performed on the fish gonads. The results showed that during observation not many fish were spawning, this was demonstrated by GSI calculations and visual observations of the gonads. The maturity stage of gonads varies from maturity stage of gonad I to IV, with GSI that varies from 0.03$0.75 \%$ for female fish and $0.001-0.65$ for male fish.
\end{abstract}

\section{KEY WORDS}

Gonad, maturity, mudskipper, Pseudapocryptes elongatus.

Pseudapocryptes elongatus (Cuvier, 1816) including members of the family of gobiidae, also called mudskippers. In Gresik and its surroundings areas, it is known of "P. elongatus". $P$. elongatus not yet known by the community because it has not been cultivated. $P$. elongatus many traded in the gresik, especially in the northern part of Gresik which is the coastal area and estuary Bengawan Solo. This fish has a soft texture and with a delicious and distinctive flavor.

To meet market demand, until now $P$. elongatus continue to be caught from its natural habitat, so it is feared there is over exploitation, because there is an indication of the catch is declining. Kottelat et al. (2013) states that in terms of conservation, the decrease in the number and size of fish is one indication of the decrease in the quantity and quality of the population. The decrease in the quantity and quality of the population of a species may lead to a decrease in genetic variation, which in turn may result in a decrease in the ability to adapt to the environment. Further impact, the species is prone to extinction.

Assess the potential $P$. elongatus having excellence in some aspects and the consideration of conditions in $P$. elongatusin natural habitats threatened kelestariannya, so $P$. elongatus need to promoted to be used as fish cultivation. Information about $P$. elongatus which includes habitats and character biology that influential on the lives of $P$. elongatusin northern waters gresik still very limited, so he damaged support the domesticated and cultivation of $P$. elongatus necessary information from various aspects of biology, of them are biology reproduction, ecology, fodder and the habit of eating, character morfometrik, genetic character and others.

Seeing the potential of $P$. elongatus that have advantages in some aspects and consider the condition of the $P$. elongatus in natural habitats that are threatened sustainability, then $P$. elongatus should be promoted to be a fish cultivation. Information on $P$. elongatus that includes habitats and biological characters that affect the life of $P$. elongatus in the northern waters of Gresik is still very limited, so that to support the domesticated and cultivation of $P$. elongatus required biological information from various aspects, such as reproductive biology, ecology, feed and eating habits, morphometric characters, and genetic characters. 
The fish reproduction character is an important biological information as a reference for conservation and domestication. Various aspects of reproductive character that can provide an overview of the reproductive capacity of fish species according to Bucholtz et al (2009) include sex ratio, the level of maturity stage, gonadosomatic index, first-size mature gonad, fecundity, and distributions of oocyte diameter.

Maturity stage is the stage of development of gonads before and after the fish spawn. Knowledge of the stages of gonad maturity is needed, among others, to predict the fish that have been and not mature gonads from stocks found in the waters, the size or age of fish first experienced mature gonads, as well as the season and frequency of spawning fish in one year. The quantitative change of maturity stage is expressed by GSI, which is a value in percent (\%), as a result of the weight ratio of gonads to fish body weight including gonads multiplied by $100 \%$. GSI value will be maximized at the time the fish will spawn and will be at least after the spawn fish (Effendie, 2002).

\section{MATERIALS AND METHODS OF RESEARCH}

The fish to be dissected, first measured in total length (TL), standard length (SL), body width (BW), height (HD), head length $(\mathrm{HL})$, caudal fin length, head volume and lateral linea (LL) . The length measurement uses a sliding threshold with a precision of $0.1 \mathrm{~mm}$, and weighed the body weight using a sartorius scale with accuracy of $0.0001 \mathrm{gr}$.

1. Taking of the gonads fish and preservation sample:

Taking fish gonads is done by dissecting fish on the abdominal portion vertically from the anus to the vertebrae, then horizontally leading to the ventral fin. When the abdomen of the fish is open, the gonads can be observed to determine the maturity stage. Gonads are taken from the gastrointestinal tract and swimming bubbles. Then the gonads are weighed and placed into a bottle of film containing $10 \%$ formalin until the gonad is submerged.

2. Determination of Gonadal Maturity stage:

The GonadalMaturity stage is determined based on the standard determination of morphological gonad maturity stage (Effendie, 2002) and through histology research. Maturity stage observations through morphology include: shape and size, weight, color and smoothness or absence of ovaries. The results were then compared with the general classification of maturity stage according to Effendie (1979. While assessment of gonadal maturity stage with histology research, observed the existence of oogonia, oocyte, ootid, egg yolk, and egg diameter.

3. Determination of Gonadosomatic Index (GSI):

The Gonadosomatic Index (GSI) can be determined by weight the fish and the gonads. Fish weights were weighed by using weight digital precision 0.01 in grams (gr). While the weight of gonad is calculated by using a sartorius scale precision of $0.0001 \mathrm{gr}$. The Gonadosomatic Index can be calculated using the formula (Effendie, 1979).

$$
G S I=\frac{G w}{w} \times 10
$$

Where: GSI = Gonad Maturity Index; Gw = Gonad Weight (gr); w = Fish weight (gr).

4. Determination of Fecundity:

Samples of gonad the $P$. elongatus which are thought to have matured gonads are selected for fecundity calculated. Pre-preserved gonads, dried and washed with aquades to remove $10 \%$ formaldehyde solution. Then,the gonad samples were placed on filter paper and dried for \pm 10 minutes. Furthermore, the gonads are divided into three parts namely the tip, middle, and base of the gonad. Each part is taken $3 \%$ to be weighed and observed the number of eggs. In this research, determination of Fecundity the $P$. elongatus is done by gravimetric method which refers to Effendie (1979). 


$$
F=\frac{G}{Q} \times N
$$

Where: $F=$ Fecundity (grains); $G=$ Weight of gonad (gr); $Q=$ Weight of sub gonad (gr); $\mathrm{N}=$ number of eggs in sub gonads (grains).

\section{RESULTS OF STUDY}

Gonad Maturity stage. Generally, male and female $P$. elongatus can be distinguished by observation on the dimorphism of the fish. Male and female $P$. elongatus have a slightly different pattern, female has a pattern that extends to the lateral linea, while the male pattern is not up to the lateral linea. Based on the surgery shows that the gonad of $P$. elongatus is located above the swim bladder.

Visual observation of fish gonad $P$. elongatus refers to $P$. papilio that has been done by Lawson, et al (2010) (Table 1). The visual observation of the gonads showed that maturity stages of male and female jaws ran vary from maturity stage 1 to 4 (Figures 1,2).

Table 1 - Description of stages of gonadal maturity stage on P. Papilio

\begin{tabular}{|c|c|c|c|}
\hline TKG & Degree of matur & Female & Male \\
\hline 1 & immature & $\begin{array}{c}\text { Gonad looks like a non transparent } \\
\text { thread }\end{array}$ & Gonad looks like a non-transparent thread \\
\hline 2 & $\begin{array}{c}\text { Immature and } \\
\text { developing }\end{array}$ & $\begin{array}{c}\text { Gonad looks bigger and the surface } \\
\text { is rough }\end{array}$ & Gonad looks bigger and the surface is rough \\
\hline 3 & Ripening & $\begin{array}{c}\text { many blood vessels on the surface } \\
\text { of the gonads. Gonad is transparent } \\
\text { yellow }\end{array}$ & $\begin{array}{c}\text { Visible many blood vessels on the surface of } \\
\text { the gonads. The color of the gonads begins to } \\
\text { whiten }\end{array}$ \\
\hline 4 & Ripe & $\begin{array}{c}\text { Gonads fill most of the space in the } \\
\text { abdominal cavity }\end{array}$ & $\begin{array}{c}\text { Gonads fill most of the space in the abdominal } \\
\text { cavity }\end{array}$ \\
\hline 5 & Ripe Running & $\begin{array}{c}\text { The egg will come out when it gets a } \\
\text { little massage }\end{array}$ & $\begin{array}{c}\text { Sperm cells will come out when they get a little } \\
\text { massage }\end{array}$ \\
\hline 6 & Spent & Abdominal cavity began to empty & Abdominal cavity began to empty \\
\hline 7 & Recovery-spent & Invisible oocytes left, reddish gonads & Invisible spermatocytes left, reddish gonads \\
\hline
\end{tabular}

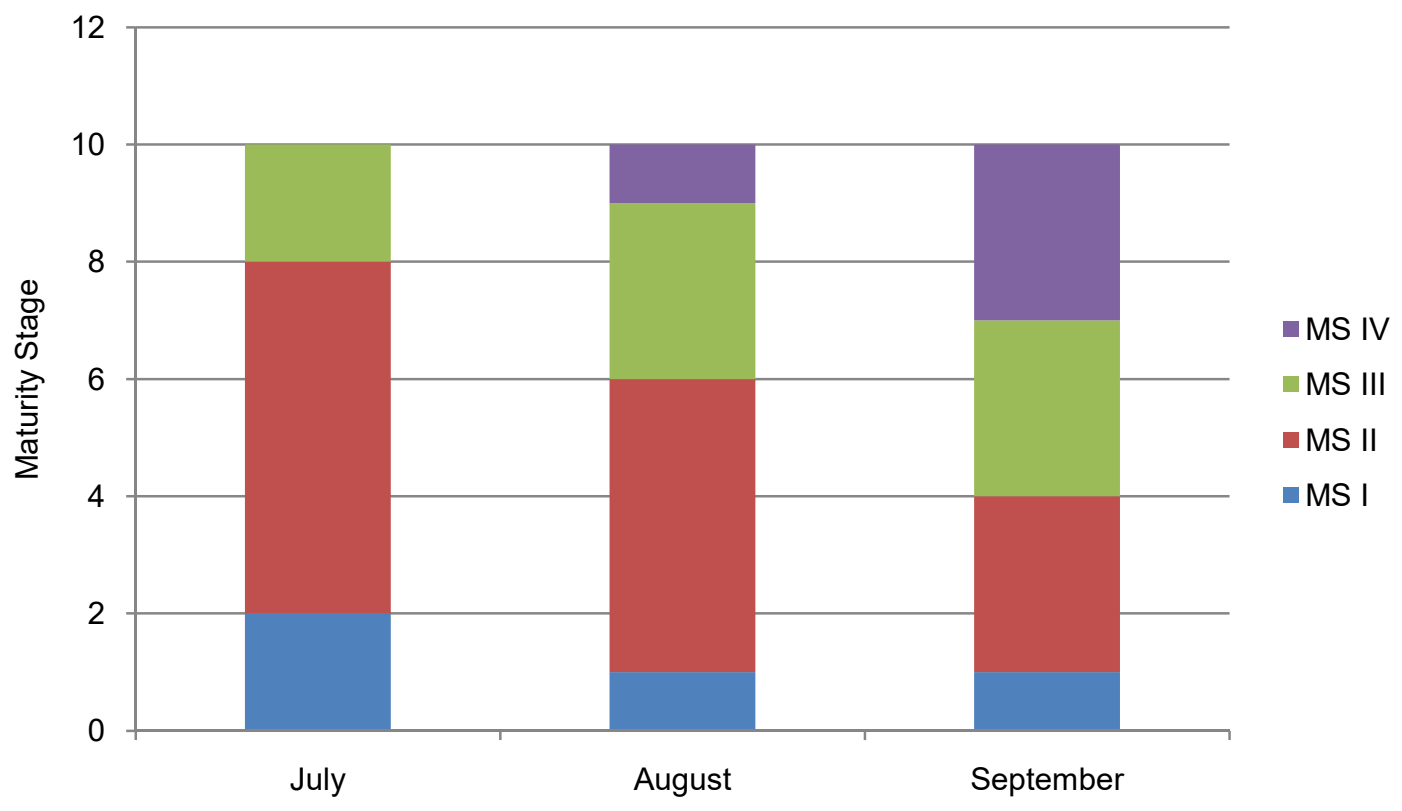

Figure 1 - The maturity stage of gonads on female $P$. elongatus based on observation months 


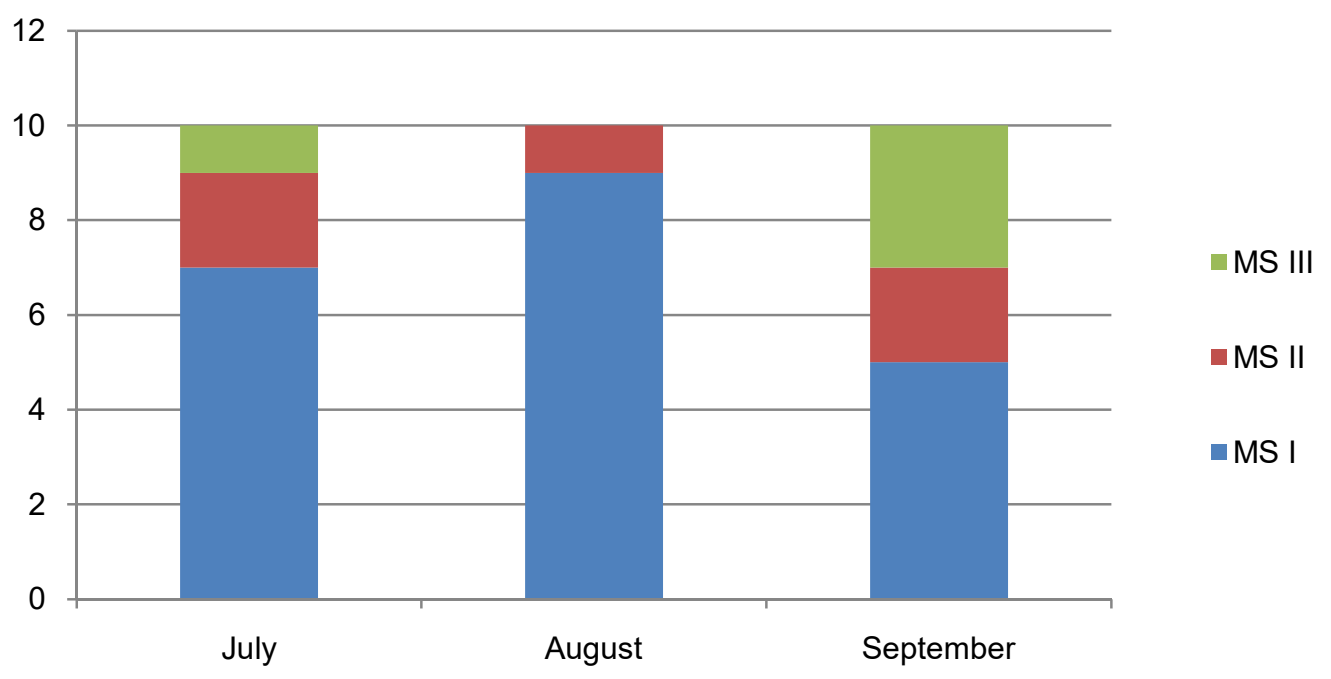

Figure 2 - The maturity stage of gonads on male $P$. elongatus by month of observation

Figure 1 showed gonad of $P$. Elongatus matures in September. In July, female gonads were not seen reaching maturity stage IV and not found in male fish $P$. elongatusmature the gonads, but it appeared to be seen maturing in September

Observation of gonad maturity is also done by calculating GSI (Gonadosomato index) presented in percent. GSI calculations show that $P$. elongatus captured from July to September does not exist in the mature condition of gonads with the largest GSI in Males $0.65 \%$ and $0.75 \%$ for females (Figure 3 ). This is also stated by Bucholtz et al (2009), that $P$. elongatus fish in China has a GSI value of $14.5 \%$ while $P$. elongatus in Pakistan has a GSI value of up to $4 \%$ in mature gonad conditions and is ready for breeding .

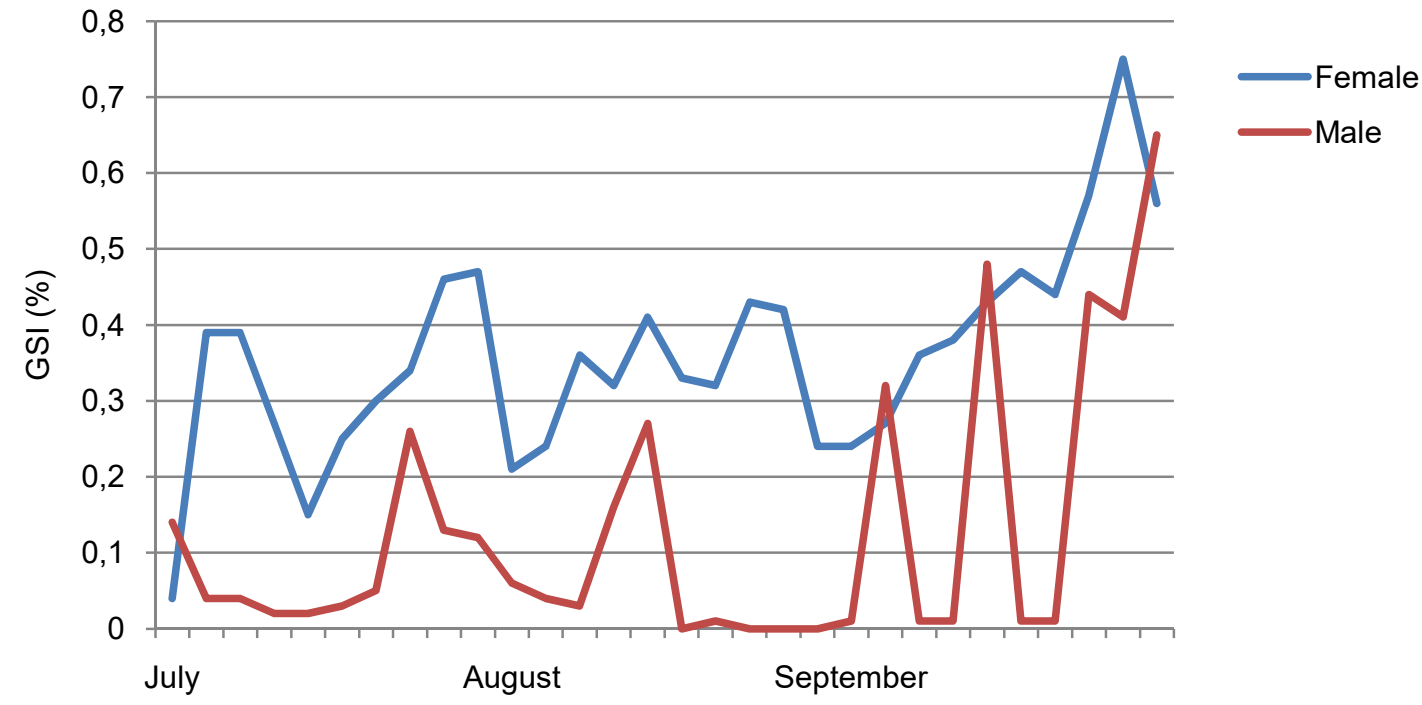

Figure 3 - The value of gonadosomatic index (\%) $P$. elongatus by month

GSI has been used to explain the development of gonads in Pike fish (Danilenko, 1983). Progressively GSI will increase with the increasing percentage of individual that will enter the spawning season (Mohammed, 2010). The most practical method for determining the spawning season in fish is by knowing the value of GSI it has (El-Greisy, 2000: Assem, 2000 and 2003; honji et al, 2006). Similarly, Efriyeldi et al. (2012), the percentage value of 
GSI changes with the change of maturity level of gonad, so it can be used to know the spawning season of a species.

Observations on gonadal maturity $P$. elongatusindicate that $P$. elongatuscaptured in July until September is not mature gonads, it is also said by Dinh, et al (2007) that $P$. elongatus will spawn at the beginning and end of the rainy season.

Fecundity. The number of eggs present in the female fish gonads before being expended for the purpose of spawning is called fecundity. Based on the calculation result, fecundity of $P$. elongatus varies between $68,334-275,656$ grains. The lowest fecundity was obtained in fish with total lenght $13 \mathrm{~cm}$ and the highest fecundity was obtained in fish with total lenght 18 (Figure 4).

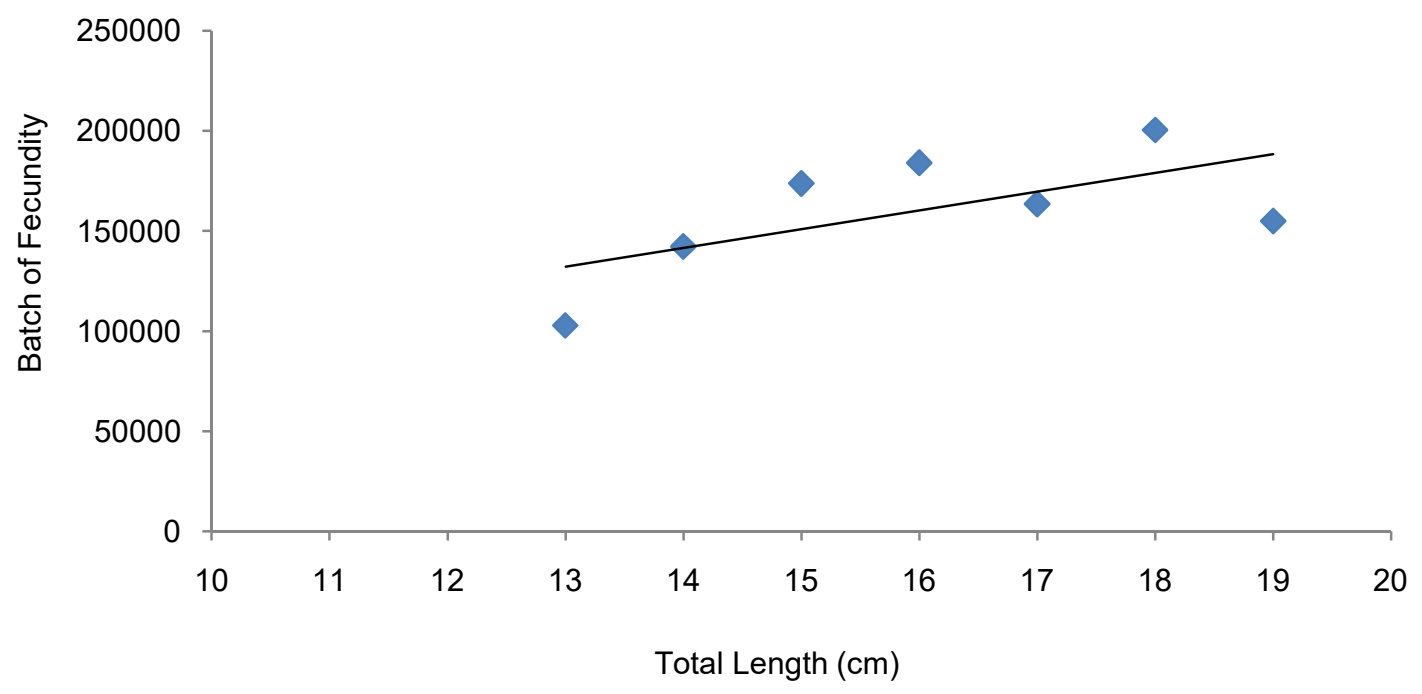

Figure 3 - The relationship between total lenght $(T L)$ and batch fecundity $(F) P$. Elongatus in the Kalilamong River

The results of the study showed that $P$. elongatusfecundity can be quite high when compared with other mudskipper fish. The results of research conducted by Dinh et al (2015) showed that fecundity of Parapocryptes seperaster as much as 6,000-11,700 grains in total length 11.9 - $21.5 \mathrm{~cm}$. In a study conducted by Sharifian et al. (2017) stated that in Boleophthalmus dussumieri has fecundity of 1,031 - 3,952 eggs per fish and P.barbarus has 900-23.933 (Udo, 2002). The batch of fecundity can affected by the geographic and water quality (Dinh, 2015).

\section{CONCLUSION}

Based on observations of the gonads of $P$. elongatus from July to September 2017, it was found that no $P$. elongatus was being ripe for either male or female gonads. This is because the observation month has not yet entered the rainy season, while $P$. elongatus is thought to spawn at the height of the rainy season until the end of the rainy season, so that in August it is seen that female P. elongatus gonad enters gonad maturity level 4 although gonad fish is still entering maturity level level 3 gonads

\section{ACKNOWLEDGEMENTS}

The research was funded by the Research and Community Service Institution Through Non-Tax State Revenue Fund (PNBP) Brawijaya University In accordance with the List of Implementation of Budget (DIPA) Brawijaya University Number DIPA-042.01.2.400919/2017. 


\section{REFERENCES}

1. Assem SS. The reproductive biology and histological characteristic of the pelagic carangid female. Caranxcrysos from the Egyptian Mediterranean sea. Ger.SocZool, 2000; 31(c); 195-215.

2. Assem SS. The reproductive biology and histological and ultrastructural characteristics of the ovary of female pelagic fish Pagelluserythrinus from the Egyptian Mediterranean urater. J Egypt Ger Soc Zool. 2003; 42:77-103.

3. BucholtzR. H, A. S. Meilvang, T. Cedhagen1 and J.T. Christensen. 2009. Biological Observations on the Mudskipper Pseudapocrypteselongatus in the Mekong Delta, Vietnam. Journal of The World Aquaculture Society. 40 (6): 711-723.

4. Danilenko TP. The reproductive cycle of the Pike, Esox Lucius L. in the Kanev Reservoir. Hydrobiology 1983; 18:21-27.

5. Dinh TP, Ambak MA, Hassan A, Phuong NT. Biology and Population dynamics of the goby pseudopocrypte selogatus in the coastal mud flat areas of the Mekong Delta, Vietnam, Pakis, J Bio Sci. 2007; 10(9):3284-3294.

6. Dinh, M. Q., Nguyen, T. T. G., dan Nguyen, T. K. T. 2015. Reproductive Biology of the Mudskipper Boleophthalmus boddarti in Soc Trang. Tap Chi Sinh Hoc. 37 (3): 362 - 369.

7. Effendie, M. I. 1979. Metode Biologi Perikanan. Bogor: Yayasan Dewi Sri.

8. Biologi Perikanan. 2002. Bogor: Yayasan Pustaka Nusatama.

9. Efriyeldi, Ditriech G. B., Ridwan, A., dan Tri, P. 2012. Perkembangan Gonad dan Musim Pemijahan Kerang Sepetang (Pharella acutidens) di Ekosisitem Mangrove Dumai, Riau. Maspari Journal. 4(2): 137 - 147.

10. El-Greisy Z. Reproductive Biology and Physiology of DiplodusSargus (Family: Spariidae) in the Mediterranean environment. Ph. D Thesis Department of Environmental studies institution of Graduate studies Alex University, 2000.

11. Fariedah, Fani., Widodo, M. S., Fadjar, M., Ashshiddiqie, H. Morphological Character The Mudskipper Pseudapocryptes Elongatus In The Gresik North Coastal Area. Proceeding international conference the 7th green technology faculty of science and technology UIN Maliki. 2016.

12. Honji RM, Vas-dos-Santos AM, Rossi WS. Identificationof the stages of ovarian maturation of the Argernnehak, Merluccuus hubbsi marini, (Teleostei: Merluccidae) advantages and disadvantages of the use of the macroscopic and microscopic scales, Neotrop. Ichthiol 2006; 443:329-337.

13. Kottelat, M. 2013. The Fishes of the Inland Waters of Southeast Asia:A Catalogue and Core Bibliography of the Fishes Known to Occur in Freshwaters, Mangroves and Estuaries. The Raffles Bulletin of Zoology. (27): 1-663.

14. Lawson, Immanuel Olugbenga. 2010. Maturation and histological character of ovaries in mudskipper, peropthalmus papilio from Lagos lagoon. Journal of American Seriesю

15. Minh, T. H., Wenresti, G. G., dan Nguyen, T. P. 2010. Fishery and Aquaculture of Juvenile Mudskipper Pseudapocryptes elongatus (Cuvier, 1816) in the Coastal Zone of Mekong Delta, Vietnam. Asian Fisheries Science. 23: 224 - 239.

16. Sharifian, S. Taherizadeh, M. R., Salarpouri, A., dan Dehghani, M. 2017. Population Structure and Reproductive Biology of theMudskipper Boleophthalmus Dussumieri Valenciennes, 1837 from the Bay of Hormozgan Province, Persian Gulf. Cah. Biol. Mar. 58: 25-32.

(C) 2017 by the authors. Licensee RJOAS, Orel, Russia. This article is an open access article distributed under the terms and conditions of the Creative Commons Attribution (CC BY) license: http://creativecommons.org/licenses/by/4.0/ 